\title{
MiniReview: COVID-19 Therapeutics
}

\author{
Amna Kaneez Fatima Raja ${ }^{1}$, Maheen Nazir $^{2}$, Farah Gul ${ }^{3}$, Mohammad Iqbal Khan ${ }^{4}$, and \\ Fouzia Sadiq ${ }^{4}$ \\ ${ }^{1}$ Army Medical College \\ ${ }^{2}$ Rawalpindi Medical University \\ ${ }^{3}$ Shifa International Hospitals Ltd \\ ${ }^{4}$ Shifa Tameer-e-Millat University
}

July 20, 2020

\begin{abstract}
As of March, 2020, Corona Virus disease 2019 (COVID-19) has catapulted to the status of a pandemic. Its rapid spread has initiated a worldwide search for appropriate therapeutics targeting the causative SARS-CoV-2 virus. Till now, the management of critical COVID-19 patients mainly revolves around the supportive therapies of supplemental oxygen and ventilatory support. However, pharmacotherapy and immunotherapy specifically intended to halt SARS-CoV-2 from exerting its effects are increasingly being incorporated into treatment regimens. COVID-19 patient care continues to evolve as the available drugs are being thoroughly investigated for their potential antiviral effects and new therapies, such as vaccines, are being developed. The list of pre-existing therapeutics that show promise against SARS-CoV-2 includes anti-virals like Remdesivir, plasma therapy, traditional Chinese medicine (TCM), anticoagulants, antibiotics, corticosteroids and several other investigational agents such as vitamin supplements and thymosin alpha one. In this comprehensive, updated review we will highlight the major prospective therapies that are currently in the arsenal against COVID-19 and where they stand in the treatment recommendations as well as a brief look at the challenges faced in Pakistan. With this review we not only hope to disseminate the accurate, recent information regarding these therapies, but also discuss the reliability of the clinical trials that have designated them to be useful against COVID-19.
\end{abstract}

\section{Introduction}

An outbreak of SARS-CoV-2 occurred in Wuhan, China in December 2019 and within a matter of a few months it progressed into a full-blown pandemic. It is responsible for a total global death toll of 505,567 and 10,304,148 confirmed cases in over 213 countries as of 29th June 2020 (worldometer). SARS-CoV-2 belongs to the family of large enveloped positive stranded RNA Corona Viruses and is the 7th virus of this group to infect humans ${ }^{1}$. It is a zoonotic virus and is transmitted through the inhalation of airborne droplets. It can trigger a respiratory tract infection which is mild in most cases but can result in severe infections in 19\% of patients according to the WHO. As such critical care has consisted of ventilation with a range of repurposed drugs and other therapies that are very much still under investigation. No specific guidelines for treatment have been set. The purpose of this review is to provide a concise overview of the therapeutics (Table 1) that have been used and / or are in developmental pipeline to treat COVID-19. 


\section{In Use}

Remdesivir (GS-5734), a nucleotide analogue, is one of the most promising drugs available against COVID-19. It is the only drug so far that has been approved by the FDA outside the context of a clinical trial albeit in emergency situations only. It has a broad spectrum anti-viral activity and has been used against Ebola as well as the SARS and MERS Corona viruses in the past ${ }^{23}$. It has shown in vitro and in vivo activity against SARS-COV-2 ${ }^{4}$. It is a small molecule inhibitor of viral RNA polymerase. It can also interfere with the Corona Virus nsp12 polymerase activity and can generate active nucleotide triphosphates which incorporate into RNA strands followed by termination of viral RNA replication ${ }^{5}$.

Several clinical trials are currently underway to further investigate its role as a therapeutic option in COVID19. Among them was a recent randomized, double-blind, placebo controlled, multi-center trial of 1063 globally dispersed patients. In the treatment group, hospitalized COVID-19 patients were administered an initial intravenous loading dose of $200 \mathrm{mg}$ Remdesivir followed by daily intravenous maintenance dose of $100 \mathrm{mg}$ for 5-9 days. The recovery time in this group was significantly shorter than that observed in the placebo group (median, 11 days vs 15 days). The incidence of adverse events (anemia, acute kidney injury, decreased creatinine clearance, pyrexia, hyperglycemia and increased aminotransferase levels) was not found to be significantly different between the two groups ${ }^{6}$.

Lopinavir/ Ritonavir belong to antiretroviral drugs and belong to protease inhibitors class. Ritonavir increases half-life of Lopinavir by inhibiting CYP450. Fixed dose combination (kaletra) has been used for the treatment of AIDS. The combination has been proposed to inhibit the SARS-CoV-2 protease chymotrypsinlike protease (3CLpro) that is necessary for the processing of the viral RNA although there is still some uncertainty as 3CLpro lacks the specific molecular site which is the target for these inhibitors ${ }^{7}$.

Lopinavir-Ritonavir have been found effective against COVID-19 when used in combination with other antivirals but not so much on their own. A multi-centered open labeled randomized study was carried out in six major hospitals of Hong Kong. Confirmed COVID-19 positive patients ( $\mathrm{n}=86)$ above the age of eighteen were randomized to the treatment group who received the triple combination of Lopinavir- Ritonavir (400mg100mg) every 12 hours, Ribavirin (400mg) every 12 hours, and subcutaneous injection of Interferon Beta-1b, three doses of eight million units on alternate days. They had a shorter median time to testing negative when compared with the control group patients $(n=41)$ treated with Lopinavir-Ritonavir only. All symptoms of the patients of the triple combination group resolved in 4 days vs 8 days in the Lopinavir-Ritonavir group. Standard care was provided to both groups. Common non-serious adverse events such as diarrhoea, nausea, fever and the raised liver enzyme ALT were observed ${ }^{8}$.

Recently, the FDA recommended against the use of Lopinavir/Ritonavir unless patients are involved in a clinical trial.

Avifavir (favipiravir) is related to Avigan, an anti-influenzal drug that is used in Japan. It is also a small molecule inhibitor of viral RNA polymerase. The median viral clearance time of patients with COVID19 who received oral Favipiravir (35 patients) was shorter than patients who received Lopinavir/Ritonavir (45 patients), 4 vs 11days. Both treatment groups were additionally treated with interferon administered by aerosol inhalation. The incidence of adverse effects was also less in the first group. They also showed more significant improvements when comparing chest imaging ${ }^{9}$. Russia has granted temporary approval for Avifavir and they will deliver approximately 60,000 courses of Avifavir to Russian hospitals in June.

Arbidol (Umifenovir) is a broad-spectrum antiviral compound. A trial was conducted at a hospital in Changzhou to compare the efficacy of Arbidol to Lopinavir/Ritonavir. Thirty-four COVID-19 patients received Lopinavir/Ritonavir at a dose of $400 \mathrm{mg} / 100 \mathrm{mg}$ twice a day for a week while 16 patients received 200mg of Arbidol thrice a day. While there was no significant difference between the duration of fever in both groups the patients of the Arbidol group reached undetectable levels of the RNA by day 14 after admission while this was not the case for $44.1 \%$ of the patients in the group receiving Lopanivir/Ritonavir ${ }^{10}$, suggesting that Arbidol may be a better alternative to Lopinavir/ Ritonavir. However, the small sample size was the 
major limitation in this study. Favipiravir was found to have better outcomes than Arbidol, although there was no difference in the mechanical ventilation rates in both groups, the fever of the Favipiravir patient group decreased earlier ${ }^{11}$.

\section{Immunotherapies}

Plasma Therapy has been successful in several other cases of viral diseases such as Ebola, Influenza H1N1, H5N1 and more importantly against the SARS and MERS Corona Viruses. Intravenous immunoglobulins (IVIG) and hyperimmunoglobulins isolated from the plasma of COVID-19 recovered patients (convalescent plasma therapy or CPT) are under investigation as sources of neutralizing antibodies against SARS-CoV$2^{1213}$.

Neutralizing antibodies can stop SARS-CoV-2 replication by preventing receptor binding, wall fusion and un-coating of the virus once inside the cytoplasm ${ }^{12}$. They also play a role in inhibiting and reversing the effects of the cytokine storm (a complex interaction between factors such as IL-6, IL-7, IL-10, G-CSF and TNF-alpha) that occurs in SARS-CoV-2. These factors cause endothelial dysfunction, coagulation and increased vascular permeability that are linked to severe symptoms ${ }^{14}$.

There have been several cases of successful plasma convalescent therapy. Among them were 10 patients with symptoms of severe COVID-19 who were given $200 \mathrm{ml}$ of CP from recovered patients with titres of neutralizing antibodies of more than 1:640. The symptoms of the patients in the treatment group improved within 3 days, C-reactive protein (CRP) levels decreased, and lymphocyte counts increased. Chest imagery analysis also showed considerable resolution of pulmonary lesions in all patients. This outcome was compared to that of a historical control group consisting of 10 patients treated in the same hospitals (without CP), with the same baseline characteristics and severity of disease. There were three fatalities in the control group compared to none in the patients receiving $\mathrm{CP}^{15}$. Moreover 5 studies, all of which were either case series or case reports, found CPT to decrease symptoms, viral load, body temperature, increase the level of neutralizing antibody over time and resolve acute respiratory distress syndrome (ARDS) with no serious side effects ${ }^{16}$. However, it is critical that plasma from newly recovered patients is collected as soon as possible because antibody titre begins to decrease from as early as four months after recovery ${ }^{17}$.

Monoclonal antibody (Mab) therapy has certain advantages over CPT such as being highly reproducible and readily available. Therefore, Mab therapy is being explored as an alternative to CPT. During investigation Mabs like CR3022 and 47D11 were found to effectively neutralize SARS-CoV-2 although in vitro ${ }^{18}$. Others such as Tocilizumab, Sarilumab, Siltuximab have an anti-inflammatory effect by blocking the IL-6 receptor a central player in the cytokine storm. A clinical trial reported positive outcomes upon administration of Tocilizumab to serious hospitalized COVID-19 patients; body temperature subsequently decreased to normal on the first day after treatment, oxygen requirement decreased by the fifth day for $75 \%$ and pulmonary lesions absolved in $90.5 \%$ of patients. Blood counts and CRP also returned to normal ${ }^{19}$.

There is currently insufficient data available for the FDA to approve for or against these Convalescent Plasma Therapy and the use antibodies.

Type 1 Interferons are a set of cytokines that are further made up of two sub-types alpha and beta. They are part of the initial immune response and are able to recognize viruses through their pattern recognition receptors (PRR) and inhibit viral replication and spread. Previous studies against SARS-CoV-1 and MERS have established that interferon 1beta would be the best candidate against COVID-19.

Interferon 1beta has shown therapeutic potential when combined with Lopinavir, Ritonavir and Ribavirin 8. Interferon alpha 2b spray has also been successfully used to decrease COVID-19 infection rates and China has recommended 5 million units of its use by vapour inhalation in combination with ribavirin ${ }^{20}$. However, their use has not been approved by the FDA outside the context of clinical trials due to their lack of efficacy against previous Corona Virus infections and their side effects.

Traditional Chinese Medicine (TCM) has been in use and has developed over 3500 years. In fact, according to reports $91.5 \%$ COVID-19 patients in China have received TCM as a part of their treatment 
(Huanget al. , 2020). The National Health Commission of the People's Republic of China has included TCM in each of the 7 guidelines it has published so far for the treatment of COVID-19.

Some common ones are HuoxiangZhengqi, LianhuaQingwen (LHQ), ShufengJiedu, XueBijing injections and Qing Fei Pau Du Tang. The most prominent proposed antiviral effects of TCM are inhibition of viral entry into host cells and the reduction of pro-inflammatory cytokines such as IL-6 and TNF-alpha. According to the National Administration of Chinese Medicine, symptoms notably improved in $60 \%$ of the 214 patients treated with Qing Fei Pau Du Tang up to 5th February $2020^{22}$. LHQ capsules are also currently under phase 2 clinical trials in the USA ${ }^{23}$. Randomized, double-blind and placebo-controlled studies are needed to test the true therapeutic potential of traditional Chinese medicines.

Anticoagulant therapy: There are increased chances of thrombosis during SARS-CoV-2 infection. ${ }^{24}$ has reported elevated levels of D-dimer, fibrinogen, and fibrinogen degradation products in critically ill COVID19. The use of low molecular heparin and unfractionated heparin has significantly been able to lower mortality rates in patients with raised D-Dimer (six times the normal level) levels ${ }^{25}$. However, there are certain challenges with anti-thrombotic drugs as they can interact with other therapies. For example, co-administration of Clopidogrel and Apixaban with antivirals such as Lopinavir and Ritonavir should be avoided. These antivirals influence the cytochrome $\mathrm{P} 450$ mediated metabolism of the anticoagulants which in turn deranges anticoagulant pharmacokinetic properties and increase the risk of side effects like hemorrhages ${ }^{26}$. There is still insufficient data to recommend for or against the prophylactic use of anti-coagulants outside the context of a clinical trial.

Antibiotics have also been used together with antivirals as a large proportion of viral respiratory infections can be associated with bacterial pneumonia and other co-infections. Patients that are receiving ventilatory support for prolonged periods of time are also at a higher risk of picking up nosocomial infections. Around $74.5 \%$ patients under critical care receive antibiotics as a part of their treatment. National Institute for Health and Care Excellence (NICE), UK has recommended the use of the broad-spectrum antibiotic Coamoxiclav and a macrolide for the treatment of severe pneumonia ${ }^{27}$. WHO has recommended the use of Ceftriaxone/Ampicillin plus a macrolide for the treatment of severe pneumonia in adults.

Tetracyclines have been proposed for use against COVID-19. These antibiotics chelate zinc to the metalloproteinases (MMPs) of target cells that bind to SARS-CoV-2. They also have anti-inflammatory actions ${ }^{28}$. Doxycycline has been able to inhibit pro-inflammatory cytokines such as IL-6 and IL-1 in vitro at doses as low as 20-40 mg/day ${ }^{29}$. DYNAMIC (DoxycYcliNeAMbulatoIre COVID-19 NCT04371952), consisting of 330 patients, has been the only study proposed to compare a treatment with doxycycline in COVID-19 patients vs a placebo group.

\section{Not Recommended}

Chloroquine and Hydroxychloroquine are potent anti-malarials with well recognized antiviral properties. These were initially recommended because of positive outcomes in various clinical trials. In a study conducted in the Guangdong and Hubei provinces, 197 COVID-19 patients who received Chloroquine had a shorter duration of fever and time to undetectable RNA levels. Hydroxychloroquine used with Azithromycin (HQ/AZ) also showed a rapid reduction in viral load of the COVID-19 patients, compared to controls. This can be attributed to the fact that these drugs are able to prevent the acidification of endosomes and cause the glycosylation of the SARS-CoV-2 cellular receptor preventing infection ${ }^{3031}$.

However, their potential lethal side effects have called for caution. The FDA has not recommended the high dose use of Chloroquine and has withdrawn permission for either of these two drugs to be used in emergency situations as of June 15th. They are only allowed in the context of a clinical trial. The European Medicine Agency has also only allowed the use of these drugs in the context of clinical trials or for chronic conditions. High dose Chloroquine (600mg twice daily for ten days) compared to low dose Chloroquine (450mg for five days twice only on the first day) has been associated with a higher mortality rate, QT 
prolongation and ventricular tachycardia ${ }^{32}$. QT prolongation interval is also a potential risk of HQ/AZ combination especially in patients with pre-existing cardiac disease ${ }^{3334}$. In another study cardiac arrest was more common in patients receiving this combination than patients who received neither drug ${ }^{35}$.

\section{In Pipeline}

Dexamethasone (Corticosteroid): So far corticosteroids have not been recommended because of their immuno-suppressive effects, but low dose dexamethasone has now been proven to reduce complications in critically infected COVID-19 patients by RECOVERY (NCT04381936), the world's largest randomized clinical trial. Over 2104 patients received $6 \mathrm{mg}$ of dexamethasone once per day for ten days. Dexamethasone was able to reduce mortality from $40 \%$ to $28 \%$ in patients on ventilation. It shows little effect on patients with mild symptoms. It is a huge prospect as dexamethasone is a cheap and widely available drug ${ }^{36}$.

Supplements: By now it has been well established that many of the complications of COVID-19 such as ARDS are the result of oxidative stress in turn due to a cytokine storm. Timely use of large dose of intravenous Vitamin $\mathrm{C}$ has the ability to oppose these effects as it is an antioxidant. High dose oral vitamin $\mathrm{C}$ also has some effect. Neither oral nor intravenous administration are associated with any side effects ${ }^{37}$.

There is an ongoing trial being conducted in Wuhan to investigate efficacy of Vitamin C in treating COVID19 associated pneumonia. A total of 140 patients have been recruited, of which some have been randomized to a placebo group. Primary outcomes such as ventilation free days within the first 28 after initiation of treatment and secondary outcomes such as organ failure scores and 28-day mortality will be compared ${ }^{38}$. In another ongoing clinical trial (NCT04342728), randomized patients (Age group 18 and above) have been randomized to four groups: those who received Vitamin C (ascorbic acid), those who received Zinc Gluconate, those who received both in combination and the last group that just received standard care. Primary end point is the time taken for $50 \%$ symptom reduction.

Vitamin D, N-acetylcysteine and Zinc supplements have been hypothesized in the treatment of SARS-CoV-2 infections because of their anti-inflammatory effects. According to ClinicalTrials.gov a phase III interventional randomized control trial (NCT04344041) has begun recruiting 260 COVID-19 patients (Age group 70 and above). They will be randomized into two groups: one receiving high dose of cholecalciferol (200,000IU) and the other receiving the normal standard dose (50000IU). The primary outcome will be the number of deaths by any cause during the fourteen days after inclusion and intervention.

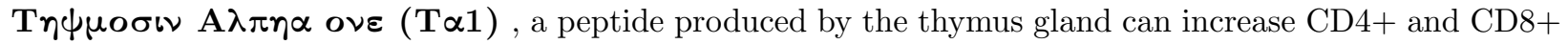
$\mathrm{T}$ cells and has been tested on COVID-19 patients. In 34 cases studies, Thymosin Alpha 1 was seen to cause an increase in CD4 and CD8 positive T cells in COVID-19 patients with severe lymphocytopenia. However, it was only seen to be beneficial for patients with counts of CD8+ and CD4+ cells population below 650/ $\mu$ and $400 / \mu$ l, respectively. Moreover, the case files of 76 critically ill patients were also retrospectively analyzed. The patients were divided into two groups; treatment group received 10mg of T $\alpha 1$ subcutaneous injection daily for at least 7 consecutive days as well as antiviral and anti-bacterial treatment while the control group received all forms of treatment provided to the first group except T $\alpha 1$. The mortality rate in the group receiving T $\alpha 1$ was lower, $11.11 \%$ vs $30 \%{ }^{39}$. Currently, 3 trials have been proposed to test the prophylactic or the therapeutic potential of thymosin. One of these has started recruiting patients. Anti-viral T cells have also been identified in COVID-19 patients so vaccines eliciting a T-cell response could also be useful ${ }^{40}$.

Baricitinib , a JAK and AAK1 inhibitor, has been suggested as possible candidate for treatment of COVID19. AAK1 may impede the entry of the virus into cells via endocytosis ${ }^{41}$. Some registered clinical trials of JAK inhibitor such as "Baracitinib in Symptomatic Patients Infected by COVID-19" NCT04320277.

Dapagliflozin is an anti-diabetic drug that is hypothesized to prevent the progression of COVID-19 as many of the complications occur in patients already suffering from cardiovascular, metabolic and renal problems 
42. Currently this drug is being tested in a phase III clinical trial involving hospitalized adult patients with COVID-19 (DARE-19 NCT04350593).

Vaccine development against SARS-CoV-2 has been essentially a continuation of the work against SARS$\mathrm{CoV}-1$ and MERS. After the outbreak of SARS-CoV-2 the structure of the S protein was rapidly determined. It has been established from previous studies that this $\mathrm{S}$ protein would be an ideal target for future vaccines. This is because the S protein interacts with an ACE-2 receptor, after binding the ACE-2 receptor mediates the entry of the virus into target cells. Potential S-protein based vaccines would stimulate an immune response against the viral S protein and would resultantly inhibit infection of target cells.

However, it is an mRNA-based SARS-CoV-2 candidate, mRNA-1273 (NCT04283461), a collaboration between Moderna and the Vaccine Research Center at the National Institutes of Health, that is among some of the furthest along in development. It involves inoculation of host cells with encapsulated viral mRNA that will then be transcribed into proteins using host machinery. These host proteins will then trigger an acquired immune response. It has recently finalized the protocol for the phase III clinical trial and based on the phase I trial a 100ug dose has been selected to best stimulate the immune system. Moderna is aiming to supply 500 million doses each year ${ }^{43}$.

Ad5-nCoV (NCT04341389) an adenovirus vaccine is in its Phase 2 trial. BNT162(NCT04380701) an mRNA vaccine, INO-4800 (NCT04336410), a DNA virus vaccine, PiCoVacc (NCT04352608), an inactivated virus vaccine and NVX-CoV2373 (NCT04368988) a protein subunit, based vaccines are all undergoing phase 1 or 2 clinical trials ${ }^{44}$.

Researchers at Oxford's Jenner Institute are in the process of development of an adenovirus vaccine vector ChAdOx1(NCT04324606). This vector has been used to develop vaccines against several other infectious agents. ChAdOx1 (recently renamed as AZD1222) contains the genetic sequence of the viral S protein which will be produced in the body after administration of the vaccine stimulating the immune response. Phase 1 trial with ChAdOx1 vaccine commenced in April of this year with more than 1000 healthy adult volunteers, many were the frontline staff of the NHS. Follow-ups are in process. Phase II and III trials are set to begin. Phase II trials will include a larger population with a wider age range ${ }^{45}$.

Imperial College London has begun phase I clinical trials of its COVID-19 vaccine candidate this month. 300 volunteers will receive two doses four weeks apart. It consists of the use of a revolutionary RNA amplifying technology. The RNA coding for the S protein will be extensively amplified and translated resulting in higher levels of antigens produced for a longer period of time which will mimic a natural infection. This self-amplifying technology shows the same efficacy in providing immune protection as conventional mRNA vaccines but with a much lower dose of RNA. Three hundred candidates will receive two doses ${ }^{46}$.

Sanofi and GSK are collaborating to develop a vaccine that contains the viral S protein that will trigger an immune response directly in candidates. Phase 1 trials are planned to begin in the later half of 2020. Around 100 vaccines are in the pre-clinical stage of development according to the WHO. Only $6 \%$ of vaccines make it out of development to be approved for public use ${ }^{44}$.

\section{Discussion and Conclusion}

While we have seen many previous pandemics and epidemics the SARS-COV-2 has brought the world at a standstill and sparked a global health crisis that has taken many by surprise with many health care systems being unable to cope. The death toll is on a continual rise and the race is on to find effective treatments. Till now the main focus has been on the prevention of spread through testing, tracing and case monitoring. Treatment has mostly involved supplemental oxygen and ventilatory support.

Rapid research is being carried out to investigate potential therapies and to re-purpose old ones. Repurposing of drugs has been the main-stay of this pandemic. With soft-ware for computational analysis available it is now possible to compare and assess the binding ability of molecular structures of available drugs to potential 
target sites. Several drugs have shown promising effects while numerous others are under investigation. Till present no specific guidelines by the WHO or the CDC, have been set in place about what exact treatment to be used.

According to ClinicalTrials.gov, 2,351 studies are registered which will investigate the COVID-19, as of June 29, 2020. It is clear that the foremost hurdle is not insufficient research but actually the lack of data from meticulously controlled clinical trials and peer reviewed research. Many studies include great deal of bias, show variable outcomes, have very small sample sizes, do not have control groups and patients are simultaneously treated with other therapeutic agents and respiratory support so it is difficult to analyze the true effect of a single drug that is under investigation. In a high-mortality situation, patients may simply not want to take part in randomized control trials with placebo groups.

In the light of current events it seems that the credibility of current research is also uncertain as can be seen by the withdrawal of the infamous Lancet paper on the 4th of June that stated that the Hydroxychloroquine (a drug that has been under the spotlight in recent days) increased the risk of mortality. The reason being was the refusal for an independent review of its dataset.

Many view a vaccine and subsequent global immunization as the end of this pandemic. However, vaccine development takes time, a compressed regulatory pathway will have to be rapidly conceived. Manufacturing vaccines in large quantities will be costly, developing countries will likely find themselves in trouble. As yet, no global organizations have taken responsibility of such a task but discussions with global stakeholders are in process and steps are being taken. If Imperial's low-cost vaccine is successful it will increase affordability and availability ${ }^{47}$.

Drug availability and shortage is also another problem in developing countries such as Pakistan. Remdesivir and Tocilizumab have been approved for use in severe infections in Pakistan. Remdesivir is in short supply while a single dose of Tocilixumab is 11,952 Pak rupees (USD 72). With a large majority of the population under the poverty line and a deteriorated government health care system such therapy is not widely available. Access to this therapy may increase after the proposed local manufacture of Remdesivir begins.

While tangible progress has been made there will have to be an even greater coordinated and co-operative global effort to identify and establish the most effective treatments.

There are unique challenges in resource limited developing countries such as Pakistan, a country which has one of the lowest funding amounts allocated to it's health-care system as a fraction of it's GDP in the world. The inadequacy of the system can be seen by the fact that there are only 0.6 beds per 1000 patients and 1503 ventilators available in government hospitals for a total population of 212.82 million. With a lack of immediate response mechanisms in place, non-existent infection tracing and tracking systems and insufficient public health centers manned by under-trained staff, the system is truly under pressure that it has never faced before. Treatment puts forth a whole set of new problems, even with regulatory bodies preventing over-pricing of drugs that are already in short supply such as Tocilizumab (priced at 11,952 Pak rupees (USD 72) and Remdesivir and others that are being hoarded they will still most likely be inaccessible to the $24.3 \%$ of the population that lives under the poverty line. Pakistan will have to develop a holistic strategy to enhance the capacity of its pharmaceutical sector as home production seems to be a credible solution of unfortunately one of several problems. It seems in cases such as this, prevention is truly better than cure. (Noreen et al., 2020)

\section{Author Contributions}

AR, MN and FS contributed to different sections of the manuscript. All authors reviewed the manuscript.

\section{Conflict of Interest}

The authors declare that the research was conducted in the absence of any commercial or financial relationships that could be construed as a potential conflict of interest.

\section{Funding}


No funding was recieved

Table Legends

Table 1. The overview of therapeutic agents for COVID-19

\section{References}

1. Andersen KG, Rambaut A, Lipkin WI, Holmes EC, Garry RF. The proximal origin of SARS-CoV-2. Nat Med . 2020;26(4):450-452.

2. Mulangu S, Dodd LE, Davey Jr RT, et al. A randomized, controlled trial of Ebola virus disease therapeutics. N Engl J Med . 2019;381(24):2293-2303.

3. Sheahan TP, Sims AC, Graham RL, et al. Broad-spectrum antiviral GS-5734 inhibits both epidemic and zoonotic coronaviruses. Sci Transl Med . 2017;9(396).

4. Pruijssers AJ, George AS, Schäfer A, et al. Remdesivir potently inhibits SARS-CoV-2 in human lung cells and chimeric SARS-CoV expressing the SARS-CoV-2 RNA polymerase in mice. 2020.

5. Li Z, Wang X, Cao D, Sun R, Li C, Li G. Rapid review for the anti-coronavirus effect of remdesivir. Drug Discov Ther . 2020;14(2):73-76. doi:10.5582/ddt.2020.01015

6. Beigel JH, Tomashek KM, Dodd LE, et al. Remdesivir for the treatment of Covid-19 - preliminary report. N Engl J Med . 2020.

7. Dorward J, Gbinigie K. Lopinavir/ritonavir: A rapid review of effectiveness in COVID-19. 2020.

8. Hung IF-N, Lung K-C, Tso EY-K, et al. Triple combination of interferon beta-1b, lopinavir-ritonavir, and ribavirin in the treatment of patients admitted to hospital with COVID-19: an open-label, randomised, phase 2 trial. Lancet . 2020;395(10238):1695-1704. doi:10.1016/s0140-6736(20)31042-4

9. Cai Q, Yang M, Liu D, et al. Experimental treatment with favipiravir for COVID-19: an open-label control study. Engineering . 2020.

10. Zhu Z, Lu Z, Xu T, et al. Arbidol monotherapy is superior to lopinavir/ritonavir in treating COVID-19. $J$ Infect . 2020.

11. Chen C, Huang J, Cheng Z, et al. Favipiravir versus arbidol for COVID-19: a randomized clinical trial. MedRxiv . 2020.

12. Nguyen AA, Habiballah SB, Platt CD, Geha RS, Chou JS, McDonald DR. Immunoglobulins in the treatment of COVID-19 infection: Proceed with caution! Clin Immunol . 2020:108459.

13. Syal K. COVID-19: herd immunity and convalescent plasma transfer therapy. J Med Virol . 2020.

14. Keith P, Day M, Perkins L, Moyer L, Hewitt K, Wells A. A novel treatment approach to the novel coronavirus: an argument for the use of therapeutic plasma exchange for fulminant COVID-19. 2020.

15. Duan K, Liu B, Li C, et al. Effectiveness of convalescent plasma therapy in severe COVID-19 patients. Proc Natl Acad Sci . 2020;117(17):9490-9496.

16. Rajendran K, Narayanasamy K, Rangarajan J, Rathinam J, Natarajan M, Ramachandran A. Convalescent plasma transfusion for the treatment of COVID-19: Systematic review. J Med Virol . 2020.

17. Cao W-C, Liu W, Zhang P-H, Zhang F, Richardus JH. Disappearance of antibodies to SARS-associated coronavirus after recovery. N Engl J Med . 2007;357(11):1162-1163.

18. Kumar GV, Jeyanthi V, Ramakrishnan S. A short review on antibody therapy for COVID-19. New Microbes New Infect . 2020:100682. 
19. Xu X, Han M, Li T, et al. Effective treatment of severe COVID-19 patients with tocilizumab. Proc Natl Acad Sci . 2020;117(20):10970-10975.

20. Sallard E, Lescure F-X, Yazdanpanah Y, et al. Type 1 interferons as a potential treatment against COVID-19. Antiviral Res . 2020:104791.

21. Huang X, Zhou M-Y, Cheng Y, et al. Opportunities and challenges of traditional Chinese medicine going abroad for COVID-19 treatment.Am J Emerg Med . 2020;(January). doi:10.1016/j.ajem.2020.06.008

22. Yang Y, Islam MS, Wang J, Li Y, Chen X. Traditional Chinese medicine in the treatment of patients infected with 2019-new coronavirus (SARS-CoV-2): a review and perspective. Int J Biol Sci . 2020;16(10):1708.

23. Gao D, Niu M, Wei S, et al. Identification of a Pharmacological Biomarker for the Bioassay-Based Quality Control of a Thirteen-Component TCM Formula (Lianhua Qingwen) Used in Treating Influenza A Virus (H1N1) Infection. Front Pharmacol . 2020;11:746.

24. Han H, Yang L, Liu R, et al. Prominent changes in blood coagulation of patients with SARS-CoV-2 infection. Clin Chem Lab Med . 2020;1(ahead-of-print).

25. Yin S, Huang M, Li D, Tang N. Difference of coagulation features between severe pneumonia induced by SARS-CoV2 and non-SARS-CoV2. J Thromb Thrombolysis . 2020:1.

26. Khan IH, Savarimuthu S, Leung MST, Harky A. The need to manage the risk of thromboembolism in COVID-19 patients. J Vasc Surg. 2020.

27. Cox MJ, Loman N, Bogaert D, O'grady J. Co-infections: potentially lethal and unexplored in COVID-19. The Lancet Microbe . 2020;1(1):e11.

28. Sodhi M, Etminan M. Therapeutic Potential for Tetracyclines in the Treatment of COVID-19. Pharmacother J Hum Pharmacol Drug Ther . 2020;40(5):487-488.

29. Conforti C, Giuffrida R, Zalaudek I, Di Meo N. Doxycycline, a widely used antibiotic in dermatology with a possible anti-inflammatory action against IL-6 in COVID-19 outbreak. Dermatol Ther . 2020.

30. Huang M, Li M, Xiao F, et al. Preliminary evidence from a multicenter prospective observational study of the safety and efficacy of chloroquine for the treatment of COVID-19. MedRxiv . 2020.

31. Gautret P, Lagier J-C, Parola P, et al. Hydroxychloroquine and azithromycin as a treatment of COVID19: results of an open-label non-randomized clinical trial. Int J Antimicrob Agents . 2020:105949.

32. Borba M, de Almeida Val F, Sampaio VS, et al. Chloroquine diphosphate in two different dosages as adjunctive therapy of hospitalized patients with severe respiratory syndrome in the context of coronavirus (SARS-CoV-2) infection: Preliminary safety results of a randomized, double-blinded, phase IIb cl. MedRxiv . 2020.

33. Chorin E, Dai M, Shulman E, et al. The QT interval in patients with COVID-19 treated with hydroxychloroquine and azithromycin. Nat Med . 2020:1-2.

34. Juurlink DN. Safety considerations with chloroquine, hydroxychloroquine and azithromycin in the management of SARS-CoV-2 infection. CMAJ . 2020;192(17):E450-E453.

35. Rosenberg ES, Dufort EM, Udo T, et al. Association of treatment with hydroxychloroquine or azithromycin with in-hospital mortality in patients with COVID-19 in New York state. Jama . 2020.

36. Horby P, Lim WS, Emberson J, et al. Effect of Dexamethasone in Hospitalized Patients with COVID-19: Preliminary Report. MedRxiv . 2020:2020.06.22.20137273. doi:10.1101/2020.06.22.20137273

37. Cheng RZ. Can early and high intravenous dose of vitamin C prevent and treat coronavirus disease 2019 (COVID-19)? Med Drug Discov . 2020;5:100028. 
38. Carr AC. A new clinical trial to test high-dose vitamin C in patients with COVID-19. Crit Care . 2020;24(1):1-2.

39. Liu Y, Pang Y, Hu Z, et al. Thymosin alpha 1 (T $\alpha 1$ ) reduces the mortality of severe COVID-19 by restoration of lymphocytopenia and reversion of exhausted T cells. Clin Infect Dis . 2020.

40. Leslie M. T cells found in coronavirus patients 'bode well' for long-term immunity. Science (80- ) . 2020;368(6493):809-810. doi:10.1126/science.368.6493.809

41. Richardson P, Griffin I, Tucker C, et al. Baricitinib as potential treatment for 2019-nCoV acute respiratory disease. Lancet (London, England) . 2020;395(10223):e30.

42. Chatterjee S. SGLT-2 inhibitors for COVID-19-A miracle waiting to happen or just another beat around the bush? Prim Care Diabetes . 2020.

43. Amanat F, Krammer F. SARS-CoV-2 vaccines: status report.Immunity . 2020.

44. Mullard A. COVID-19 vaccine development pipeline gears up.Lancet . 2020;395(10239):1751-1752.

45. Koirala A, Joo YJ, Khatami A, Chiu C, Britton PN. Vaccines for COVID-19: the current state of play. Paediatr Respir Rev . 2020.

46. McKay PF, Hu K, Blakney AK, et al. Self-amplifying RNA SARS-CoV-2 lipid nanoparticle vaccine induces equivalent preclinical antibody titers and viral neutralization to recovered COVID-19 patients.bioRxiv . 2020 .

47. Lurie N, Saville M, Hatchett R, Halton J. Developing Covid-19 vaccines at pandemic speed. $N E n g l J$ Med . 2020;382(21):1969-1973.

\begin{tabular}{|c|c|c|c|c|}
\hline $\begin{array}{l}\text { Table 1. The } \\
\text { overview of } \\
\text { therapeutic } \\
\text { agents for } \\
\text { COVID-19 }\end{array}$ & $\begin{array}{l}\text { Table } 1 \text {. The } \\
\text { overview of } \\
\text { therapeutic } \\
\text { agents for } \\
\text { COVID-19 }\end{array}$ & $\begin{array}{l}\text { Table } 1 \text {. The } \\
\text { overview of } \\
\text { therapeutic } \\
\text { agents for } \\
\text { COVID-19 }\end{array}$ & $\begin{array}{l}\text { Table } 1 \text {. The } \\
\text { overview of } \\
\text { therapeutic } \\
\text { agents for } \\
\text { COVID-19 }\end{array}$ & $\begin{array}{l}\text { Table } 1 . \text { The } \\
\text { overview of } \\
\text { therapeutic } \\
\text { agents for } \\
\text { COVID-19 }\end{array}$ \\
\hline References & Treatment & Treatment & $\begin{array}{l}\text { Mechanism of } \\
\text { Action }\end{array}$ & Status $^{a, b}$ \\
\hline Li et al., 2020 & Anti-Viral & Remdesivir & $\begin{array}{l}\text { Viral RNA } \\
\text { polymerase } \\
\text { inhibitor }\end{array}$ & $\begin{array}{l}\text { FDA-approved for } \\
\text { emergency } \\
\text { situations }\end{array}$ \\
\hline $\begin{array}{l}\text { Dorward \& } \\
\text { Gbinigie, } 2020\end{array}$ & & Lopinavir/Ritonavir & $\begin{array}{l}\text { Viral } \\
\text { chymotrypsin-like } \\
\text { protease }\left(3 \mathrm{CL}^{\text {pro }}\right) \\
\text { inhibitors }\end{array}$ & $\begin{array}{l}\text { FDA recommends } \\
\text { against the use of } \\
\text { Lopinavir/Ritonavir } \\
\text { outside the } \\
\text { context of clinical } \\
\text { trials }\end{array}$ \\
\hline $\begin{array}{l}\text { Nguyen et al., } 2020 \\
\text { Keith et al., } 2020\end{array}$ & Immunotherapy & $\begin{array}{l}\text { Convalescent } \\
\text { Plasma Therapy } \\
\text { Monoclonal } \\
\text { Antibodies }\end{array}$ & $\begin{array}{l}\text { Neutralise virus; } \\
\text { Anti-inflammatory }\end{array}$ & $\begin{array}{l}\text { Insufficient data } \\
\text { available for the } \\
\text { FDA to approve for } \\
\text { or against these } \\
\text { investigational } \\
\text { immunotherapies } \\
\text { outside of clinical } \\
\text { trials }\end{array}$ \\
\hline
\end{tabular}




\begin{tabular}{|c|c|c|c|c|}
\hline $\begin{array}{l}\text { Table 1. The } \\
\text { overview of } \\
\text { therapeutic } \\
\text { agents for } \\
\text { COVID-19 }\end{array}$ & $\begin{array}{l}\text { Table 1. The } \\
\text { overview of } \\
\text { therapeutic } \\
\text { agents for } \\
\text { COVID-19 }\end{array}$ & $\begin{array}{l}\text { Table 1. The } \\
\text { overview of } \\
\text { therapeutic } \\
\text { agents for } \\
\text { COVID-19 }\end{array}$ & $\begin{array}{l}\text { Table 1. The } \\
\text { overview of } \\
\text { therapeutic } \\
\text { agents for } \\
\text { COVID-19 }\end{array}$ & $\begin{array}{l}\text { Table 1. The } \\
\text { overview of } \\
\text { therapeutic } \\
\text { agents for } \\
\text { COVID-19 }\end{array}$ \\
\hline $\begin{array}{l}\text { Sallard et al., } \\
2020\end{array}$ & & Type 1 Interferon & $\begin{array}{l}\text { Inhibits viral } \\
\text { replication and } \\
\text { spread, induces } \\
\text { viral resistance in } \\
\text { cells }\end{array}$ & $\begin{array}{l}\text { FDA recommends } \\
\text { against the use of } \\
\text { interferons } \\
\text { outside the } \\
\text { context of clinical } \\
\text { trials }\end{array}$ \\
\hline Yang et al., 2020 & $\begin{array}{l}\text { Traditional } \\
\text { Chinese } \\
\text { Medicine }\end{array}$ & $\begin{array}{l}\text { Huoxiang } \\
\text { Zhengqi, Lian- } \\
\text { huaQingwen, } \\
\text { Shufeng Jiedu } \\
\text { and XueBijing } \\
\text { injection }\end{array}$ & $\begin{array}{l}\text { Anti- } \\
\text { inflammatory; } \\
\text { Inhibit viral } \\
\text { replication and } \\
\text { alter viral } \\
\text { morphology in } \\
\text { vitro }\end{array}$ & $\begin{array}{l}\text { NHC-approved in } \\
\text { China }\end{array}$ \\
\hline $\begin{array}{l}\text { Cox et al., } 2020 \\
\text { Sodhi \& Etminan, } \\
2020 \text { Conforti et al., } \\
2020\end{array}$ & Antibiotics & $\begin{array}{l}\text { Co-amoxiclav; } \\
\text { Ceftriaxone } \\
\text { Ampicillin Clar- } \\
\text { ithromycin/Azithrom } \\
\text { \& Macrolides } \\
\text { Tetracycline } \\
\text { Doxycycline }\end{array}$ & $\begin{array}{l}\text { Treat bacterial } \\
\text { co-infections; } \\
\text { Inhibit binding of } \\
\text { (\$rARS-CoV-2 to } \\
\text { host cells } \\
\text { (Tetracycline); } \\
\text { Anti-inflammatory } \\
\text { (Doxycycline) }\end{array}$ & $\begin{array}{l}\text { NICE (UK) and } \\
\text { WHO recommends } \\
\text { the use of } \\
\text { broad-spectrum } \\
\text { antibiotic and a } \\
\text { macrolide for the } \\
\text { treatment of severe } \\
\text { pneumonia }\end{array}$ \\
\hline $\begin{array}{l}\text { Huang et al., } 2020 \\
\text { Gautret et al., } 2020\end{array}$ & Anti-Malarial & $\begin{array}{l}\text { Chloroquine, } \\
\text { Hydroxychloroquine }\end{array}$ & $\begin{array}{l}\text { Interfere with } \\
\text { pH-dependent, } \\
\text { endosome-mediated } \\
\text { viral entry into host } \\
\text { cells and viral } \\
\text { replication. }\end{array}$ & $\begin{array}{l}\text { FDA recommends } \\
\text { against the high } \\
\text { dose use of } \\
\text { Chloroquine }\end{array}$ \\
\hline $\begin{array}{l}\text { Han et al., } 2020 \text { Yin } \\
\text { et al., } 2020\end{array}$ & Anti-Coagulant & Heparin & $\begin{array}{l}\text { May prevent } \\
\text { thrombosis }\end{array}$ & $\begin{array}{l}\text { Insufficient data } \\
\text { available for the } \\
\text { FDA to approve for } \\
\text { or against } \\
\text { anti-coagulants } \\
\text { outside of clinical } \\
\text { trials }\end{array}$ \\
\hline Horby et al., 2020 & Corticosteroid & Dexamethasone & Anti-inflammatory & $\begin{array}{l}\text { RECOVERY Trial } \\
\text { NCT04381936 }\end{array}$ \\
\hline Cheng, 2020 & Supplement & $\begin{array}{l}\text { Vitamin C Vitamin } \\
\text { D Zinc }\end{array}$ & $\begin{array}{l}\text { Anti-oxidants; } \\
\text { Anti-inflammatory }\end{array}$ & $\begin{array}{l}\text { NCT04342728 } \\
\text { NCT04344041 }\end{array}$ \\
\hline Liu et al., 2020 & Hormone & Thymosin alpha one & $\begin{array}{l}\text { Restores T-cell } \\
\text { count }\end{array}$ & $\begin{array}{l}\text { NCT04320238 } \\
\text { (Recruiting) } \\
\text { NCT04428008 } \\
\text { NCT04268537 }\end{array}$ \\
\hline $\begin{array}{l}\text { Richardson et al., } \\
2020\end{array}$ & JAK-Inhibitor & Baricitinib & $\begin{array}{l}\text { Impedes } \\
\text { endocytosis of } \\
\text { virus into host } \\
\text { cell }\end{array}$ & NCT04320277 \\
\hline
\end{tabular}




\begin{tabular}{|c|c|c|c|c|}
\hline $\begin{array}{l}\text { Table 1. The } \\
\text { overview of } \\
\text { therapeutic } \\
\text { agents for } \\
\text { COVID-19 }\end{array}$ & $\begin{array}{l}\text { Table 1. The } \\
\text { overview of } \\
\text { therapeutic } \\
\text { agents for } \\
\text { COVID-19 }\end{array}$ & $\begin{array}{l}\text { Table 1. The } \\
\text { overview of } \\
\text { therapeutic } \\
\text { agents for } \\
\text { COVID-19 }\end{array}$ & $\begin{array}{l}\text { Table 1. The } \\
\text { overview of } \\
\text { therapeutic } \\
\text { agents for } \\
\text { COVID-19 }\end{array}$ & $\begin{array}{l}\text { Table 1. The } \\
\text { overview of } \\
\text { therapeutic } \\
\text { agents for } \\
\text { COVID-19 }\end{array}$ \\
\hline Chatterjee, 2020 & Anti-Diabetic & Dapagliflozin & $\begin{array}{l}\text { Reduced the } \\
\text { complications of } \\
\text { COVID-19 } \\
\text { especially in high } \\
\text { risk patients }\end{array}$ & $\begin{array}{l}\text { DARE-19 } \\
\text { NCT04350593 }\end{array}$ \\
\hline \multirow[t]{7}{*}{$\begin{array}{l}\text { Amanat \& } \\
\text { Krammer, } 2020 \\
\text { Mullard, } 2020\end{array}$} & Vaccines & $\begin{array}{l}\text { mRNA-1273, } \\
\text { mRNA vaccine }\end{array}$ & $\begin{array}{l}\text { Induce host immune } \\
\text { response against } \\
\text { viral antigens. }\end{array}$ & NCT04283461 \\
\hline & & $\begin{array}{l}\mathrm{Ad} 5 \text {-nCoV, } \\
\text { adenovirus vector } \\
\text { vaccine }\end{array}$ & & NCT04341389 \\
\hline & & $\begin{array}{l}\text { BNT162, mRNA } \\
\text { vaccine }\end{array}$ & & NCT04380701 \\
\hline & & $\begin{array}{l}\text { INO- } 4800, \text { DNA } \\
\text { virus vaccine }\end{array}$ & & NCT04336410 \\
\hline & & $\begin{array}{l}\text { PiCoVacc, } \\
\text { inactivated virus } \\
\text { vaccine }\end{array}$ & & NCT04352608 \\
\hline & & $\begin{array}{l}\text { NVX-CoV2373, } \\
\text { protein subunit } \\
\text { based vaccine }\end{array}$ & & NCT04368988 \\
\hline & & $\begin{array}{l}\text { ChAdOx1 } \\
\text { (AZD1222), } \\
\text { adenovirus vector } \\
\text { vaccine }\end{array}$ & & NCT04324606 \\
\hline
\end{tabular}

anformation on COVID-19 Treatment, Prevention and Research [Internet]. COVID-19 Treatment Guidelines. 2020 [cited 17 June 2020]. Available from: https://www.covid19treatmentguidelines.nih.gov/

${ }^{\mathrm{b}} \mathrm{NCT}$ numbers represent www.clinicaltrials.gov identifiers 